\title{
Physico-chemical characteristics of Suez Bay water during 2006-2007
}

\author{
Mohamed A. Hamed ${ }^{1}$; Yosry A. Soliman ${ }^{1}$; Ahmed E. Khodir ${ }^{2}$; \\ Aida H. Soliman ${ }^{2}$; Nadia A. El Agroudy ${ }^{1}$ and Fatma Hussein ${ }^{3}$ \\ 1- National Institute of Oceanography and Fisheries, Suez, Egypt \\ 2- Suez Canal University, Faculty of Science \\ 3- El- Safa Medical Center, Health affairs, Suez, Egypt
}

\begin{abstract}
Surface and bottom water samples were collected seasonally from eight

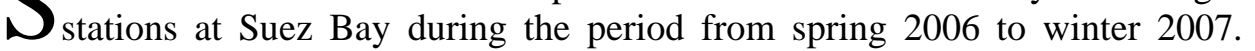
Water temperature, $\mathrm{pH}$, salinity, dissolved oxygen, nitrite, nitrate, ammonia and dissolved inorganic phosphate were determined in each sample. The results indicated that, the annual mean range of concentration of these parameters for the surface water were $22.00-23.00^{\circ} \mathrm{C}, 8.10-8.28,41.16-42.22 \%$, $8.76-10.17$ $\mathrm{mgO}_{2} / \mathrm{l}, 1.54-3.23 \mu \mathrm{M} \mathrm{NO}_{2}-\mathrm{N} / \mathrm{l}, 6.77-17.85 \mu \mathrm{M} \mathrm{NO}_{3}-\mathrm{N} / \mathrm{l}, 3.59-12.13 \mu \mathrm{M} \mathrm{NH}_{3}-$ $\mathrm{N} / \mathrm{l}$ and 0.44-2.56 $\mu \mathrm{M} \mathrm{PO}_{4}-\mathrm{P} / \mathrm{l}$ respectively. The corresponding values for bottom water were $21.50-22.38^{\circ} \mathrm{C}, 8.12-8.19,41.11-41.86 \%$ o, 8.58-9.53 mg $0_{2} / \mathrm{l}$, 1.72-3.23 $\mu \mathrm{M} \mathrm{NO} \mathrm{NO}_{2}-\mathrm{N} / \mathrm{l}, 5.25-16.32 \mu \mathrm{M} \mathrm{NO} \mathrm{NO}_{3}-\mathrm{N} / \mathrm{l}, 2.79-8.89 \mu \mathrm{M} \mathrm{NH}_{3}-\mathrm{N} / \mathrm{l}$ and $0.35-2.12 \mu \mathrm{M} \mathrm{PO}_{4}-\mathrm{P} / \mathrm{l}$ respectively. Generally, the present data indicated that the concentration of the measured parameters were relatively high at the northwestern coast of the Bay and decreased eastward (Sinai side). This reflects the high intensive disposal of sewage and industrial effluents in the western and north-western parts of the Bay.
\end{abstract}

Key words: Suez Bay, hydrography, nutrients, Physico, chemical characteristics

\section{INTRODUCTION}

The area of investigation in the present study is the Suez Bay, located between longitude $32^{\circ} 28^{\prime}$ and $32^{\circ} 34^{`}$ latitude $29^{\circ} 54^{\prime}$ and $29^{\circ} 75^{\prime} \mathrm{N}$, where changes in the chemical and physical parameters may be detected seasonally. The Bay is a shallow extension of the Gulf of Suez, roughly eltic in shape, with its major axis in the NE-SW direction. The average length along the major axis is $13.2 \mathrm{~km}$; its average width along the minor axis is $8.8 \mathrm{~km}$, the mean depth is $10 \mathrm{~m}$ and its horizontal surface area is $77.13 \mathrm{Km}^{2}$ (Hamed, 1992).

In recent years, the problems of sewage pollution of Suez coastal waters have become a point of local concern. Signs of this kind of pollution have already been observed in the last few years along the shores of Suez (Soliman, 1999). The disposal of the untreated sewage may be harmful concerning its possible hygienic and aesthetical effects and its impact on fauna and flora in the marine environment. The Suez Bay water receives a considerable amount of drainage water from different sources. Such effluents amounted to about $1,140,305 \mathrm{~m}^{3} /$ day coming from oil refineries, fertilizer plant, power station, Textile Company and wastewater treatment plant. The wastes dumped also from 
the ship traffic to the Suez Canal and from the large number of fishing boats in the study area (Soliman, 1999). These conditions may lead in future to unbalance in the environmental condition. The hydrography and chemistry of the Suez Bay were studied by several authors. Abd Alla et al. (1994) reported that the west coast of the Suez Bay is richer in the nutrient salts followed in decreasing order to the northwest part, then the east coast and that can be due to the disposal of sewage and industrial discharges in the western and northwestern regions of the Bay.

Nasser and Hamed (2003) showed that ammonia formed about $60.71 \%$ of total inorganic nitrogen in Suez Bay with an annual average of $9.15 \mu \mathrm{M} / \mathrm{l}$. Besides, they stated that the nitrite concentrations were between $1.61 \mu \mathrm{M} / \mathrm{l}$ during winter and $0.26 \mu \mathrm{M} / \mathrm{l}$ during autumn; nitrate was between $11.54 \mu \mathrm{M} / \mathrm{l}$ during autumn and zero $\mu \mathrm{M} / \mathrm{l}$ during winter and phosphate were between 1.78 during winter and $0.27 \mu \mathrm{M} / \mathrm{l}$ during autumn.

Fahamy et al (2005) stated that the nutrient levels in Suez Bay during 2003 were fluctuated between 3.87 and $14.82 \mu \mathrm{M} / \mathrm{l}, 10.29$ and $17.86 \mu \mathrm{M} / \mathrm{l}$ and $<0.03$ and $0.21 \mu \mathrm{M} / \mathrm{l}$ for ammonia, nitrite, nitrate and phosphate, respectively.

The hydrographic condition and some of the chemical parameters related with the rate of growth of fouling organisms in Suez Bay water were studied by the Soliman (1999).

The objectives of this work are to evaluate the levels of some physicochemical parameters in the Suez Bay waters.

\section{Sampling and description of the study area}

\section{MATERIALS AND METHODS}

The Suez Bay area is located at the northern part of the Gulf of Suez. It is considered as the exchange water between the Red sea and Mediterranean Sea. Surface and bottom water samples were collected using Nansen bottle from eight stations distributed along the Suez Bay from spring 2006 to winter 2007 (Fig.1).

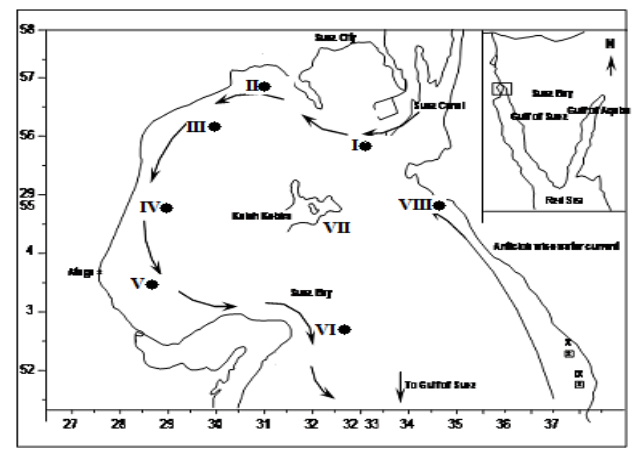

Fig. (1). Study area and sampling stations during 2006-2007, I (Port-Tawfiqe), II (El-Zeitiat),III (El-Kabanon), IV (NIOF),V (Ataqa),VI (Adabiya),VII (Green Island) and VIII (AyunMusa). 
Stations from I-VI are located in the north-western side of the Bay, their waters are mainly industrial wastes (Table 1). From two large refineries (Suez petroleum and El-Nasr petroleum companies). Station VII is located in the middle of Suez Bay and called the Green Island. Station VIII is located at the eastern side of the Bay, which is relatively far from the pollution sources and it can be considered as a control station.

Table (1). The average daily effluents in Suez Bay water from industrial and treated sewage effluents during 2006

\begin{tabular}{|c|c|}
\hline Source & Average daily effluents $\mathrm{m}^{3} /$ day \\
\hline Oil refineries & 540.000 \\
\hline Fertilizers company & 136.555 \\
\hline Power plants & 176.800 \\
\hline Sewage treatment plant & 260.000 \\
\hline Food industry & 2.400 \\
\hline Spinning \&waving industry & 124.550 \\
\hline Sum & 1.140 .305 \\
\hline
\end{tabular}

\section{Procedure}

The water temperature was measured in situ using a protected thermometer (attached to the Nansen bottle). The $\mathrm{pH}$ vof the water samples were determined using portable $\mathrm{pH}$ meter (Orion research model 210 digital). Salinity was determined using salinometer (model YSI 33). Dissolved oxygen was carried out according to Grasshoff, (1983). In field, oxygen bottles were filled carefully with water to avoid air bubbles. Dissolved oxygen was fixed immediately with $1 \mathrm{ml}$ of manganous sulphate and $1 \mathrm{ml}$ of $\mathrm{KOH}-\mathrm{KI}$ solution, in laboratory, concentrated $\mathrm{H}_{2} \mathrm{SO}_{4}$ was added to dissolve the precipitate. $50 \mathrm{ml}$ of each sample was titrated against $0.01 \mathrm{~N}$ sodium thiosulphte solution using starch as indicator.

The dissolved nutrient salts were analyzed immediately in water samples. Dissolved inorganic phosphorous, nitrite, nitrate and ammonia were measured calorimetrically following the method described in Grasshoff, (1983) by using UV-visible single beam spectrophotometer (Beckman model DU6). 


\section{Water temperature}

\section{RESULTS AND DISCUSSION}

The water circulation could clearly affect the transport mechanism of contaminated water in the area of investigation. It is known that water from the Suez Gulf enters the Bay from the eastern side (Sinai side) and discharges the Bay, from the western side. Therefore, there is a persistent anticlockwise circulation in the bay which enhances the pollution in the western side rather than the eastern one. A reverse circulation of water usually occurs in autumn (Morcos, 1960), enhances the dispersion of pollutants along the Bay, especially the western part. In winter, the southwest wind becomes sufficiently strong to produce high agitation in the Suez Bay region. Such wind movement leads to concentrate the pollutants at the Northwestern part.

Temperature is one of the major factors which directly affects animal and plant life in the sea. The absolute surface values varied between a minimum of $19.00{ }^{\circ} \mathrm{C}$ at station I during winter 2007 and a maximum of $28^{\circ} \mathrm{C}$ at the same station during summer season. The bottom values ranged between 18.00 and $27.00^{\circ} \mathrm{C}$ during winter 2007 and summer 2006, respectively. Based on the annual values, the lowest mean values $\left(22.00\right.$ and $\left.21.50^{\circ} \mathrm{C}\right)$ and the mean highest values $\left(23-22.38^{\circ} \mathrm{C}\right)$ were recorded for both surface and bottom waters, respectively (Figures $2 \& 3$ and Tables $2 \& 3$ ). From the above results, high temperatures occurred in summer, while low values were observed in winter and the Bay water are directly affected by solar radiations and seasonal changes in air temperature and due to the shallowness of the Bay water, thermal stratification was rarely detected.

\section{pH-value}

The $\mathrm{pH}$ plays an important role in many of life processes. It is affected greatly by photosynthetic activity of aquatic organisms. The $\mathrm{pH}$ values in the present study were found to lie on the alkaline side. The data in Figures. (2\&3) and Tables $(2 \& 3)$ showed regional variations in the $\mathrm{pH}$ values with lower values during summer and autumn (8.15) and little higher ones during spring and winter (8.18-8.22). The $\mathrm{pH}$ values in the surface water showed relatively high levels comparing with those recorded in bottom water. The high surface $\mathrm{pH}$-values are mainly related to the increase in photosynthetic activity in the surface euphotic zone. Juday et al. (1924), Philip (1927) and Hutchinson (1957) reported that the increase in the rate of photosynthesis raises the $\mathrm{pH}$-value as a result of the consumption of carbon dioxide and subsequent increase in dissolved oxygen which had been observed in the Bay during spring blooming.

\section{Salinity (\%o)}

In the present study salinity showed a narrow range of variations (Tables $2 \& 3)$. The bay water is characterized by having more or less constant salinity values. It ranged between $40.88 \%$ and $42.30 \%$, with a very small gradient $1.42 \%$. In spite of the considerable amount of drainage water discharged into the bay water (about $24,000 \mathrm{~m}^{3}$ per hour), no real dilution in the bay water was 
observed and no salinity value below $40.00 \%$, was found. The surface salinity of Suez Bay ranged between a maximum of 42.30 \%o, during autumn 2006 at station I and a minimum of 41.02 \%o during spring 2006 at station V. In bottom water, the maximum salinity of $42.05 \%$ was noticed during autumn 2006 at station I, while the minimum salinity of 40.88 \%o was recorded during the same season at station VIII (Figures 2\&3). According to Morcos (1970), the mean sea level at Suez Bay attains its lowest value in September and October due to the evaporation and mixing of the surface water with more saline deep water through turbulence and in the present study the surface salinity was mostly high and reach its maximum seasonal average of 41.63\%o (Autumn, 2006). Prior to minimum water level, the net flow is directed from the bay to the Gulf associated by Suez Canal an intrusion of the Mediterranean seawater through the northern part of the Suez canal and warm and less saline water from the Gulf enters the bay during winter months under the effect of the prevailing longitudinal currents in the Red Sea and the prevailing wind, resulting in pilling of water at the northern end (El-Sabh, 1966).
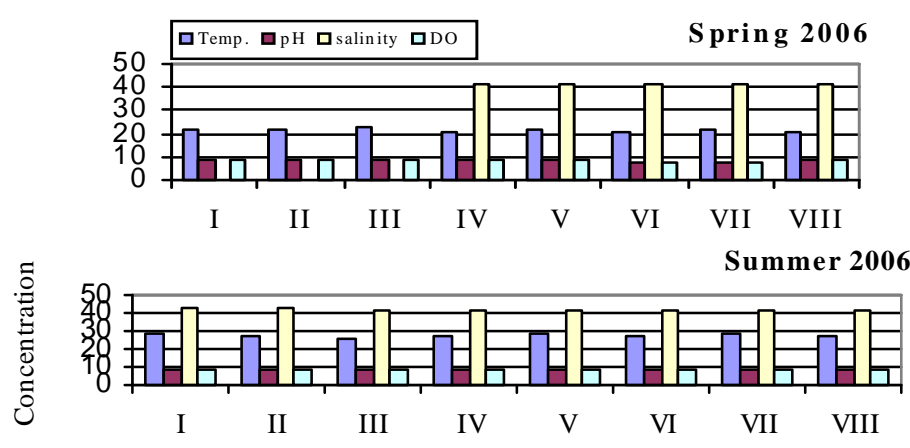

Autumn 2006

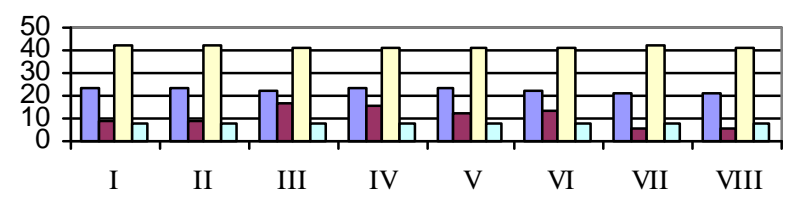

Winter 2007

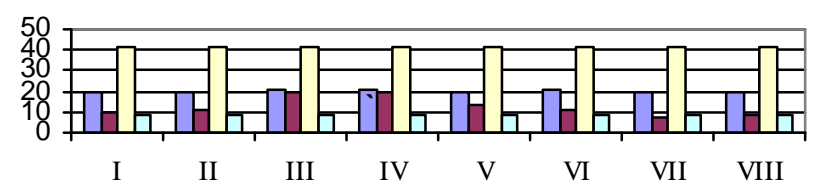

Fig. (2) Seasonal variations of temperature $\left({ }^{\circ} \mathrm{C}\right), \mathrm{pH}$, salinity (\%o) and dissolved oxygen (mg $\mathrm{O}_{2} / \mathrm{l}$ )at different sits of Suez Bay during 2006-2007 (Surface water). 

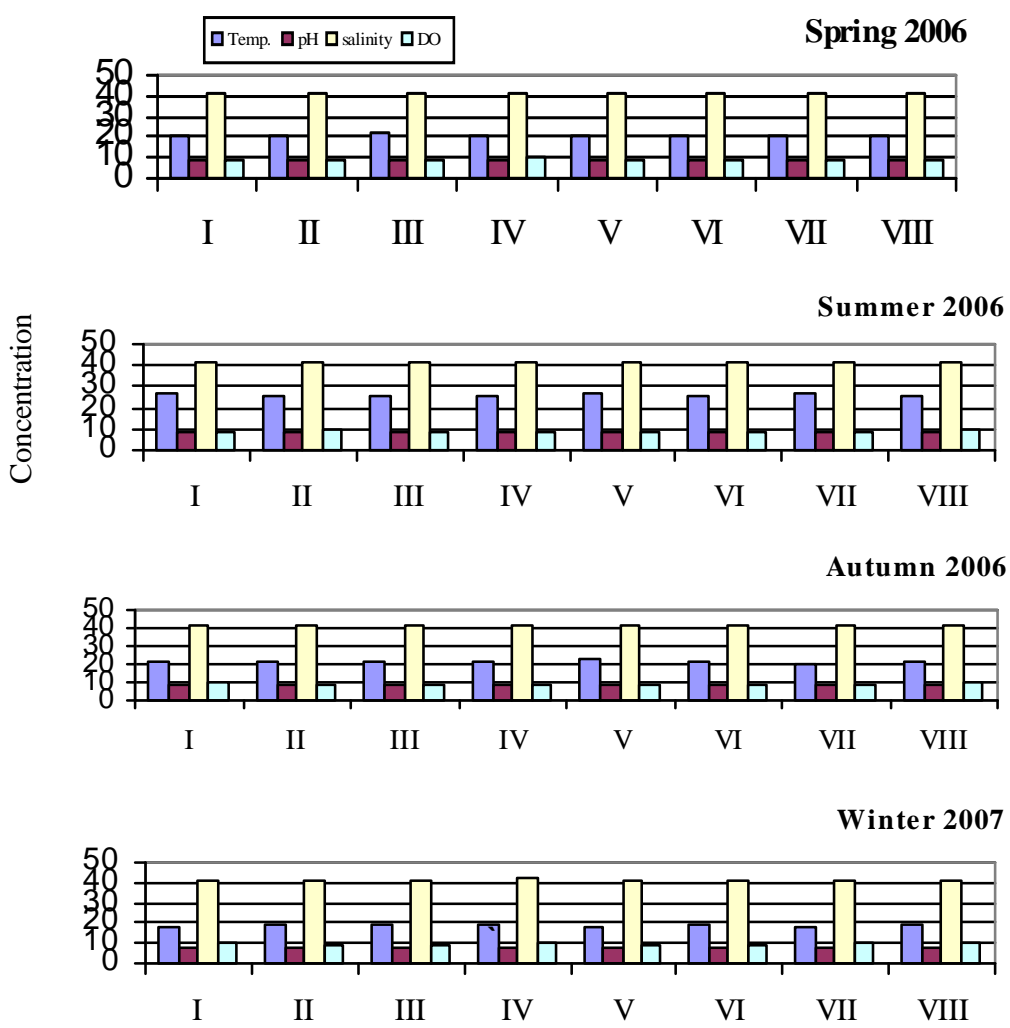

Fig. (3): Seasonal variations of temperature $\left({ }^{\circ} \mathrm{C}\right)$, $\mathrm{pH}$, salinity (\%o) and dissolved oxygen (mg $\mathrm{O}_{2} / \mathrm{l}$ )at different sits of Suez Bay during 2006-2007 (bottom water)

\section{Dissolved oxygen}

The annual and seasonal variations of dissolved oxygen in Suez Bay water are given in Figures (2\& 3 ) and Tables (2\& 3). The seasonal values of dissolved oxygen in the Bay water varied between (8.14-8.36),(8.06-8.25),(8.098.21) and (8.11-8.30) $\mathrm{mg} / \mathrm{l}$ for surface water and (8.17-8.23),(8.09-8.18),(8.098.19) and (8.12-8.20) for the bottom water during spring ,summer ,autumn 2006 and winter 2007 with a mean values of 8.22 , 8.14,8.15 and 8.18 for surface water and 8.20, 8.13,8.14 and $8.16 \mathrm{mg} / \mathrm{l}$ for bottom water. The maximum oxygen content of $10.95 \mathrm{mg} / \mathrm{l}$ was recorded at the surface water in station I during winter, while the minimum concentration of $8.10 \mathrm{mg} / \mathrm{l}$ was recorded at bottom water in sites VI and V during summer and autumn 2006. The above mentioned results indicated that, the dissolved oxygen values increased during spring and decreased during summer and this may be attributed to the increase of temperature during the summer, which causes decreasing in the degree of solubility of atmospheric oxygen gas and due to the increase in oxygen 
consumption during decomposition of organic matters and the oxidation of chemicals from effluents of different sources (Cole,1979).

Table (2). The annual range and mean concentrations of the surface water samples from Suez Bay water during 2006-2007.

\begin{tabular}{|c|c|c|c|c|c|c|c|c|c|}
\hline \multicolumn{2}{|c|}{ Location } & Temp. 'C & $\mathbf{p H}$ & S\%o & $\begin{array}{c}\text { DO } \\
\mathrm{mg} / \mathrm{l}\end{array}$ & $\begin{array}{l}\mathrm{NO}_{2}-\mathrm{N} \\
\mathrm{\mu} \mathrm{mol} / \mathrm{l}\end{array}$ & $\begin{array}{l}\mathrm{NO}_{3}-\mathrm{N} \\
\mathrm{mol} / \mathrm{l}\end{array}$ & $\underset{\mathrm{NH}_{3} \_\mathrm{N}}{\mathrm{mol} / \mathrm{l}}$ & $\mathrm{PO}_{4}-\mathrm{N}$ \\
\hline \multirow[t]{2}{*}{ I } & Range & $\begin{array}{c}19.00 \\
- \\
28.00 \\
\end{array}$ & $\begin{array}{c}8.14 \\
- \\
8.24 \\
\end{array}$ & $\begin{array}{c}41.80 \\
- \\
42.56 \\
\end{array}$ & $\begin{array}{c}9.50 \\
- \\
9.95 \\
\end{array}$ & $\begin{array}{c}1.66 \\
- \\
2.18 \\
\end{array}$ & $\begin{array}{c}7.90 \\
- \\
12.60 \\
\end{array}$ & $\begin{array}{c}4.95 \\
- \\
7.15 \\
\end{array}$ & $\begin{array}{c}0.40 \\
- \\
0.69 \\
\end{array}$ \\
\hline & Mean & 23.00 & 8.19 & 42.22 & 10.17 & 1.94 & 9.76 & 6.22 & 0.53 \\
\hline \multirow[t]{2}{*}{ II } & Range & $\begin{array}{c}19.00 \\
- \\
27.00\end{array}$ & $\begin{array}{c}8.14- \\
8.20\end{array}$ & $\begin{array}{c}41.72 \\
- \\
42.28\end{array}$ & $\begin{array}{c}9.50 \\
- \\
10.36\end{array}$ & $\begin{array}{c}1.80 \\
- \\
2.32\end{array}$ & $\begin{array}{c}8.99 \\
- \\
13.85\end{array}$ & $\begin{array}{c}4.95 \\
- \\
6.30\end{array}$ & $\begin{array}{c}0.58 \\
- \\
0.86\end{array}$ \\
\hline & Mean & 22.75 & 8.17 & 42.04 & 9.88 & 2.12 & 10.92 & 5.68 & 0.72 \\
\hline \multirow[t]{2}{*}{ III } & Range & $\begin{array}{c}21.00 \\
- \\
26.00 \\
\end{array}$ & $\begin{array}{l}8.20- \\
8.36\end{array}$ & $\begin{array}{c}41.54 \\
- \\
41.76 \\
\end{array}$ & $\begin{array}{c}8.20 \\
- \\
9.35 \\
\end{array}$ & $\begin{array}{c}2.56 \\
- \\
3.82 \\
\end{array}$ & $\begin{array}{c}14.85 \\
- \\
20.85\end{array}$ & $\begin{array}{c}8.38 \\
- \\
16.70 \\
\end{array}$ & $\begin{array}{c}2.16 \\
- \\
3.04 \\
\end{array}$ \\
\hline & Mean & 22.88 & 8.28 & 41.63 & 8.76 & 3.23 & 17.85 & 12.13 & 2.56 \\
\hline \multirow[t]{2}{*}{ IV } & Range & $\begin{array}{c}21.00 \\
- \\
27.00\end{array}$ & $\begin{array}{c}8.17- \\
8.28\end{array}$ & $\begin{array}{c}41.36 \\
- \\
41.60\end{array}$ & $\begin{array}{c}8.25 \\
- \\
9.66\end{array}$ & $\begin{array}{c}2.44 \\
- \\
3.52\end{array}$ & $\begin{array}{c}13.65 \\
- \\
19.25\end{array}$ & $\begin{array}{c}8.10 \\
- \\
10.85\end{array}$ & $\begin{array}{c}1.56 \\
- \\
2.12\end{array}$ \\
\hline & Mean & 23.00 & 8.22 & 41.49 & 8.91 & 2.98 & 16.64 & 9.64 & 1.87 \\
\hline \multirow[t]{2}{*}{$\mathrm{V}$} & Range & $\begin{array}{c}19.00 \\
- \\
28.00 \\
\end{array}$ & $\begin{array}{c}8.10- \\
8.19\end{array}$ & $\begin{array}{c}41.02 \\
- \\
41.44 \\
\end{array}$ & $\begin{array}{c}8.70 \\
- \\
9.35 \\
\end{array}$ & $\begin{array}{c}1.88 \\
- \\
2.86\end{array}$ & $\begin{array}{c}10.79 \\
- \\
15.78\end{array}$ & $\begin{array}{c}5.92 \\
- \\
9.11\end{array}$ & $\begin{array}{c}1.08 \\
- \\
1.64\end{array}$ \\
\hline & Mean & 23.00 & 8.15 & 41.20 & 8.99 & 2.42 & 13.07 & 7.69 & 1.36 \\
\hline \multirow[t]{2}{*}{ VI } & Range & $\begin{array}{c}21.00 \\
- \\
27.00 \\
\end{array}$ & $\begin{array}{l}8.10- \\
8.15\end{array}$ & $\begin{array}{c}41.18 \\
- \\
4150 \\
\end{array}$ & $\begin{array}{c}8.50 \\
- \\
9.20\end{array}$ & $\begin{array}{c}1.33 \\
- \\
2.32 \\
\end{array}$ & $\begin{array}{c}9.24 \\
- \\
14.80\end{array}$ & $\begin{array}{c}4.95 \\
- \\
7.30\end{array}$ & $\begin{array}{c}0.78 \\
- \\
1.50\end{array}$ \\
\hline & Mean & 22.75 & 8.13 & 41.30 & 8.83 & 1.97 & 12.02 & 6.34 & 1.02 \\
\hline \multirow[t]{2}{*}{ VII } & Range & $\begin{array}{c}19.00 \\
- \\
28.00\end{array}$ & $\begin{array}{c}8.06- \\
8.14\end{array}$ & $\begin{array}{c}41.40 \\
- \\
41.88 \\
\end{array}$ & $\begin{array}{c}9.12 \\
- \\
10.22 \\
\end{array}$ & $\begin{array}{c}0.70 \\
- \\
1.90\end{array}$ & $\begin{array}{c}5.21 \\
- \\
8.25\end{array}$ & $\begin{array}{c}3.12 \\
- \\
4.30 \\
\end{array}$ & $\begin{array}{c}0.32 \\
- \\
0.68 \\
\end{array}$ \\
\hline & Mean & 22.50 & 8.10 & 41.65 & 9.66 & 1.54 & 6.77 & 3.81 & 0.49 \\
\hline \multirow[t]{2}{*}{ VIII } & Range & $\begin{array}{c}19.00 \\
- \\
26.00\end{array}$ & $\begin{array}{c}8.10- \\
8.16\end{array}$ & $\begin{array}{c}41.12 \\
- \\
41.25\end{array}$ & $\begin{array}{c}9.50 \\
- \\
10.12\end{array}$ & $\begin{array}{c}0.96 \\
- \\
1.92\end{array}$ & $\begin{array}{c}4.64 \\
- \\
9.32\end{array}$ & $\begin{array}{c}3.12 \\
- \\
4.10\end{array}$ & $\begin{array}{c}0.32 \\
- \\
0.56\end{array}$ \\
\hline & Mean & 22.00 & 8.13 & 41.16 & 9.83 & 1.56 & 6.99 & 3.59 & 0.44 \\
\hline
\end{tabular}

Table (3). The annual range and mean concentrations of the bottom water samples from Suez Bay water during 2006-2007.

\begin{tabular}{|c|c|c|c|c|c|c|c|c|c|}
\hline \multicolumn{2}{|c|}{ Location } & Temp. 'C & $\mathrm{pH}$ & S\%o & $\begin{array}{c}\mathrm{DO} \\
\mathrm{mg} / \mathrm{l}\end{array}$ & $\begin{array}{c}\mathrm{NO}_{2}-\mathrm{N} \\
\mu \mathrm{mol} / \mathrm{l}\end{array}$ & $\begin{array}{l}\mathrm{NO}_{3}-\mathrm{N} \\
\mu \mathrm{mol} / \mathrm{l}\end{array}$ & $\begin{array}{l}\mathrm{NH}_{3} \_\mathrm{N} \\
\mu \mathrm{mol} / \mathrm{l}\end{array}$ & $\begin{array}{l}\mathrm{PO}_{4}-\mathrm{N} \\
\mu \mathrm{mol} / \mathrm{l}\end{array}$ \\
\hline \multirow{2}{*}{ I } & Range & $18.00-27.00$ & $8.12-8.18$ & $41.65-42.02$ & $9.04-9.88$ & $1.40-1.94$ & $5.12-10.96$ & $4.10-6.44$ & $0.30-0.52$ \\
\hline & Mean & 22.00 & 8.15 & 41.86 & 9.53 & 1.72 & 7.48 & 5.32 & 0.41 \\
\hline \multirow{2}{*}{ II } & Range & $19.00-26.00$ & $8.09-8.17$ & $41.48-41.90$ & $9.18-9.54$ & $1.49-2.14$ & $6.85-10.32$ & $4.10-5.80$ & $0.52-0.70$ \\
\hline & Mean & 22.00 & 8.12 & 41.71 & 9.35 & 1.89 & 8.46 & 4.87 & 0.61 \\
\hline \multirow{2}{*}{ III } & Range & $19.00-25.00$ & $8.15-8.22$ & $41.60-42.00$ & $8.50-9.60$ & $2.56-3.82$ & $12.80-18.77$ & $6.56-11.30$ & $1.88-2.31$ \\
\hline & Mean & 22.13 & 8.19 & 41.79 & 9.09 & 3.23 & 16.32 & 8.89 & 2.12 \\
\hline \multirow{2}{*}{ IV } & Range & $19.50-26.00$ & $8.14-8.23$ & $41.57-42.00$ & $8.64-9.78$ & $2.06-2.75$ & $10.55-17.33$ & $7.05-8.40$ & $1.23-1.96$ \\
\hline & Mean & 22.13 & 8.18 & 41.80 & 9.18 & 2.49 & 14.63 & 7.77 & 1.66 \\
\hline \multirow{2}{*}{$\mathrm{V}$} & Range & $18.50-27.00$ & 8.14-8.22 & 40.88-41.36 & $8.10-9.10$ & $1.52-2.55$ & $8.89-15.45$ & $5.33-8.50$ & $0.87-1.42$ \\
\hline & Mean & 22.38 & 8.18 & 41.20 & 8.62 & 2.08 & 11.85 & 6.83 & 1.12 \\
\hline \multirow{2}{*}{ VI } & Range & $19.50-26.00$ & $8.12-8.19$ & $41.02-41.25$ & $8.10-9.08$ & $1.06-2.06$ & $9.87-13.62$ & $4.20-5.75$ & $0.70-1.64$ \\
\hline & Mean & 22.13 & 8.16 & 41.13 & 8.58 & 1.73 & 10.98 & 5.02 & 0.99 \\
\hline \multirow{2}{*}{ VII } & Range & $18.50-26.50$ & $8.09-8.17$ & $41.28-41.58$ & $8.82-9.80$ & $0.92-2.14$ & 6.84-9.78 & $3.96-5.20$ & $0.45-0.74$ \\
\hline & Mean & 21.50 & 8.13 & 41.41 & 9.19 & 1.74 & 8.12 & 4.62 & 0.56 \\
\hline \multirow{2}{*}{ VIII } & Range & $19.00-26.00$ & $8.12-8.18$ & 41.05-41.18 & $9.20-9.70$ & $0.82-1.75$ & $3.20-7.14-$ & $2.35-3.20$ & $0.28-0.36$ \\
\hline & Mean & 21.75 & 8.15 & 41.11 & 9.39 & 1.74 & 5.25 & 2.79 & 0.35 \\
\hline
\end{tabular}




\section{Nutrients}

The most important forms of nutrients in seawater of the inorganic nitrogen are nitrate, nitrite and ammonia. The concentrations of these nutrients usually lie in the range 0.1-35 $\mu \mathrm{mol} / \mathrm{NO}_{3}-\mathrm{N} / \mathrm{l}, 0.01-3 \mu \mathrm{mol} / \mathrm{l} \mathrm{NO} \mathrm{NO}_{2}-\mathrm{N} / \mathrm{l}$ and $0.15-3 \mu \mathrm{mol} / \mathrm{l} \mathrm{NH}_{3}-\mathrm{N} / \mathrm{l}$ in oxygenated waters (Riley and Chester, 1971).

\section{Nitrite $\left(\mathrm{NO}_{2}-\mathbf{N}\right)$}

Riley and Chester (1971) have pointed out that the nitrite content in the water is primarily of importance in studying the nitrogen cycle in the sea, because of its intermediate position in oxidation-reduction processes between ammonia and nitrate.

In the present study, the absolute values of nitrite in the surface water samples varied between $0.70 \mu \mathrm{mol} / \mathrm{l}$ at station VII to $4.95 \mu \mathrm{mol} / \mathrm{l}$ at III in spring season with annual average of $2.30 \mu \mathrm{mol} / \mathrm{l}$. The bottom values reached their maximum, i.e. $3.82 \mu \mathrm{mol} / \mathrm{l}$ at station III in spring 2006 and their minimum, i.e. $0.82 \mu \mathrm{mol} / \mathrm{l}$ at station VIII in summer 2006. The highest annual station average of nitrite at the surface was recorded at station III, i.e.3.23 $\mu \mathrm{mol} / \mathrm{l}$, while the lowest, i.e. $1.54 \mu \mathrm{mol} / \mathrm{l}$ was at station VII. The corresponding bottom values ranged between 1.72 and $3.23 \mu \mathrm{mol} / \mathrm{l}$ at stations I and III, respectively (Figures 4 \& 5 and Tables 2 \& 3).

The above mentioned results indicated that, the levels of nitrite showed a regular seasonal fluctuation, and increased during spring and decreased during summer season which mainly attributed to biologically uptake of nitrite into cellular amino-acid by photosynthetic activities of plankton and action of transmins enzyme which decrease the nitrite value.

\section{Nitrate $\left(\mathrm{NO}_{3}-\mathrm{N}\right)$}

Nitrate is the final oxidation product of nitrogen compounds in seawater. It is generally considered the only thermodynamically stable oxidation species of nitrogen in the presence of oxygen in seawater and the concentration of nitrate was much higher than that of nitrite (Sillen, 1961).

The seasonal variations in the surface and bottom values of nitrate in the Suez Bay water are shown in Figures 4 \& 5 and Tables 2 \& 3 indicate that an increase in nitrate values in spring and winter and decrease in summer and autumn. The absolute values for surface water fluctuated between 8.25 and $20.85 \mu \mathrm{mol} / \mathrm{l}$ at station III in spring season 2006. In the bottom waters, the values were slightly lower and ranged between 7.14 and $18.77 \mu \mathrm{mol} / \mathrm{l}$ at station III in spring season 2006.The annual average values were 11.75 and $10.39 \mu$ $\mathrm{mol} / \mathrm{l}$ in the surface and bottom layers, respectively. The highest annual average, i.e. $17.85 \mu \mathrm{mol} / \mathrm{l}$ occurred at station III, while the lowest exists at station VII, i.e. $6.77 \mu \mathrm{mol} / \mathrm{l}$. The pattern in the bottom layer followed to a great extent that of the surface water layer. 

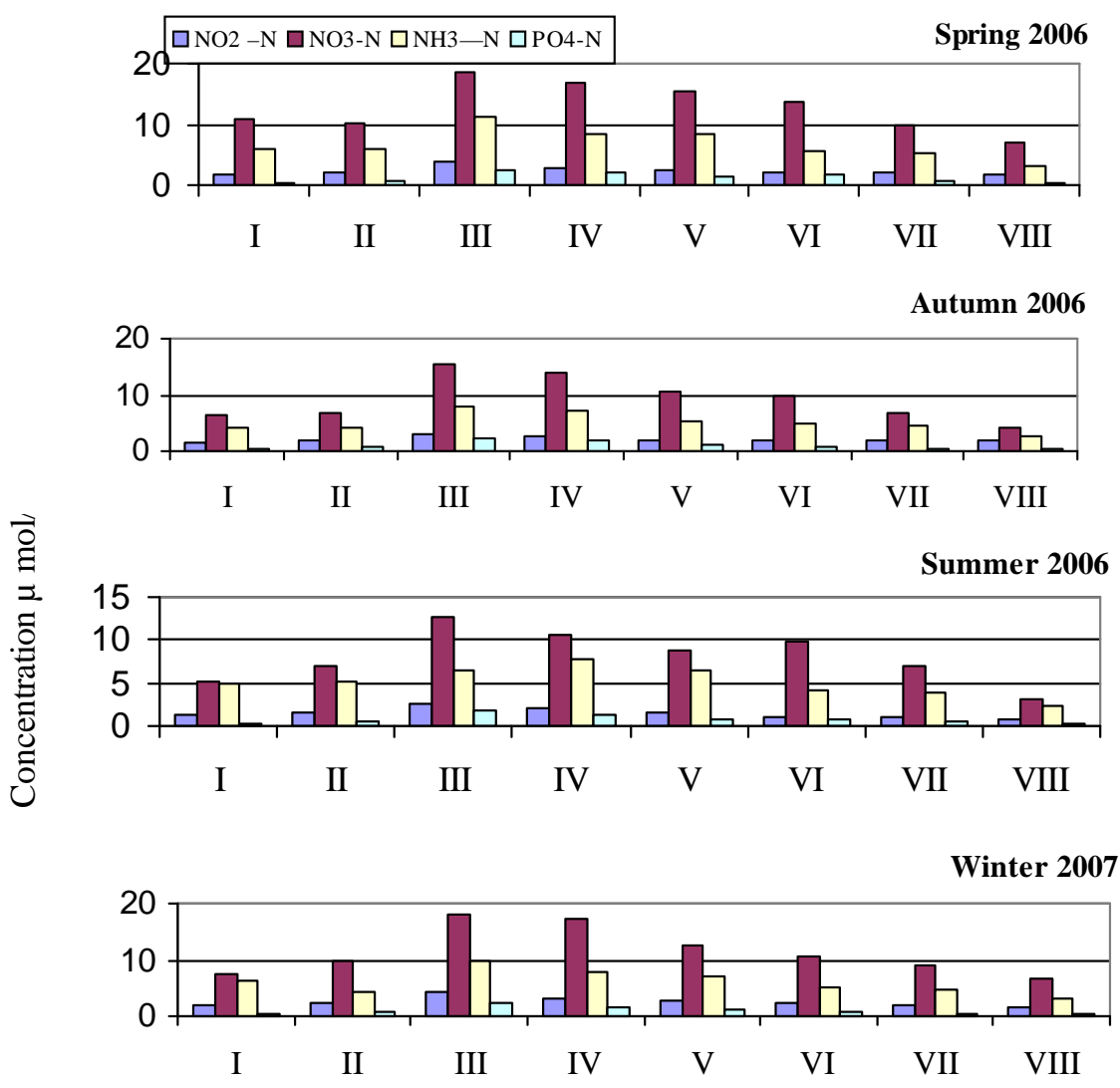

Fig. (4) Seasonal variations of nutrient salts $(\mu \mathrm{M})$ at different sits of Suez Bay during 2006-2007 (Surface water)

Compared to other results, the nitrate values recorded during this study are remarkably high (Table 6). The variations of nitrate content in the Bay water were affected by different factors, the discharge of waste water into the Bay through different outfalls such as the new treatment of wastewater of Suez city in Attaka area, the concentration of dissolved oxygen, water temperature, mixing and aeration, uptake by phytoplankton, nitrification and denitification as well as decomposition from bottom sediments. In the present study, the low values of nitrate in summer may be due to the increase in nitrate uptake by the booming phytoplankton developed in the area during this warm season (Zentara and kamykowski, 1977).

Ammonia( $\left.\mathrm{NH}_{3}-\mathbf{N}\right)$

The occurrence of ammonia in seawater depends on the intermittent relationships between the different biological and chemical processes operating 
in the regeneration of organic nitrogenous materials and also on a chief nitrogenous excretory product of many aquatic organisms especially zooplankton. In the present study, the seasonal and annual concentrations of ammonia were higher than these of nitrite but much lower than these of nitrate.

The absolute surface water nitrates varied between $3.12 \mu \mathrm{mol} / \mathrm{l}$ at stations VII and VIII during summer 2006 and $16.70 \mu \mathrm{mol} / \mathrm{l}$ at station III during spring 2006 with an annual average of $6.89 \mu \mathrm{mol} / \mathrm{l}$. The bottom values ranged between 2.35 and $11.30 \mu \mathrm{mol} / \mathrm{l}$ at station VIII and III in summer and spring, respectively, with an annual average of $5.76 \mu \mathrm{mol} / \mathrm{l}$. Based on annual averages, the surface water values varied between, 3.59 and $12.13 \mu \mathrm{mol} / \mathrm{l}$ at stations III and VIII, respectively. The corresponding bottom values ranged between a minimum of 2.79 at station VIII and a maximum at station III (Figures $4 \& 5$ and Tables 2\& 3).

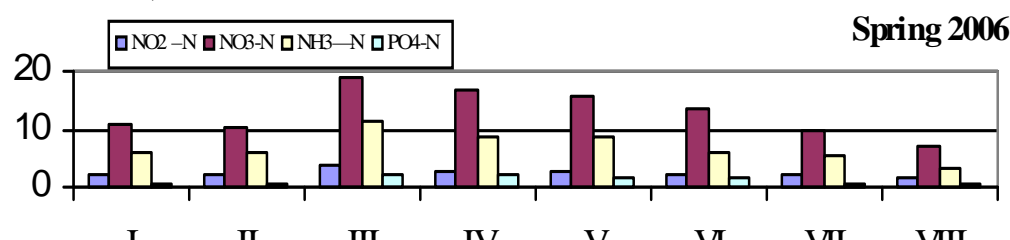

Autumn 2006
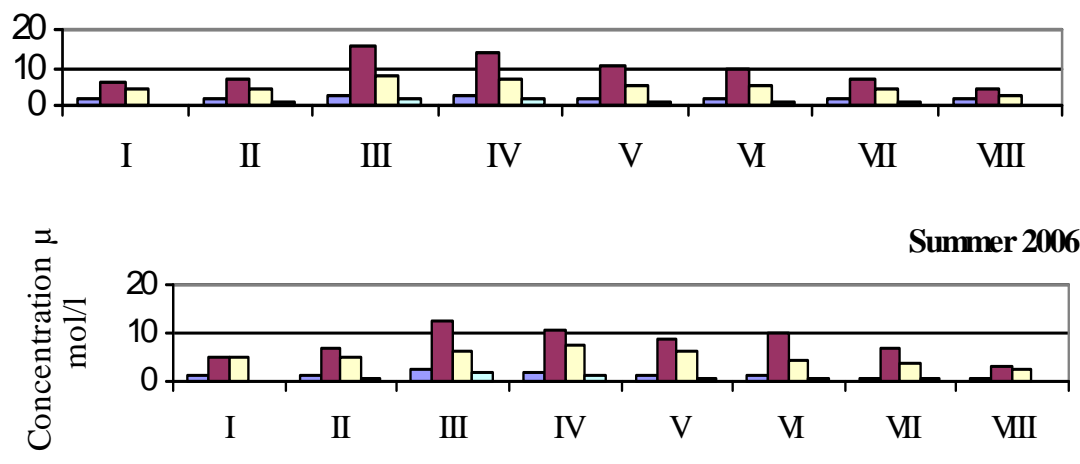

Winter 2007

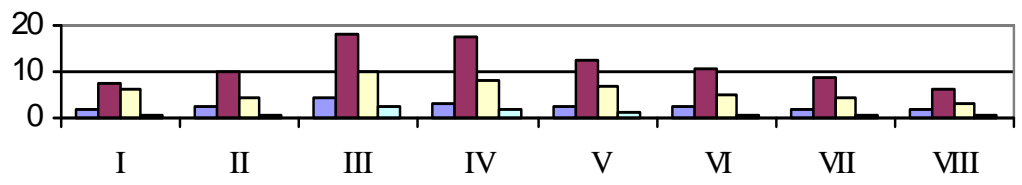

Fig.(5)Seasonal variations of nutrient salts $(\mu \mathrm{M})$ at different sits of Suez bay during 2006-2007 (bottom water)

From the above results it was clear that the ammonia was relatively concentrated at the surface water than at the bottom and this may be attributed to the allochonous origin of ammonia derived from the waste discharged into the 
Bay water. The lower values of ammonia during summer may be due to nitrification processes in which ammonia transformed into nitrite and nitrate. Also the $\mathrm{pH}$ has a marked influence on the concentration of un-ionized ammonia that exists in equilibrium with ionized ammonia and hydroxide ions, so ammonia is more toxic in alkaline water than in acidic ones.

From the data of ammonia in Table (6), we can declare that the study area can be considered under eutrophic condition.

\section{Dissolved inorganic phosphorus (DIP)}

Phosphorus is one of the most important nutrient elements in the marine environment. According to Liebig's Low of minimum, both phosphorus and nitrogen are important factors controlling the growth and reproduction of phytoplankton (Riley and Chester 1971).Soluble inorganic phosphate has been regarded as being present exclusively as monophoshpate $\left(\mathrm{HPO}_{4}{ }^{2-}\right)$ or dihydrogen phosphate $\left(\mathrm{H}_{2} \mathrm{PO}_{4}^{-}\right)$ions, with only negligible amounts of $\mathrm{PO}_{4}{ }^{3-}$ or free phosphoric acid (Cooper,1948).

During the study period (Figures $2 \& 3$ and Tables $2 \& 3$ ), the absolute surface values of DIP in the Bay water varied between 0.32 and $3.04 \mu \mathrm{mol} / \mathrm{l}$ (average $1.13 \mu \mathrm{mol} / \mathrm{l}$ ) at stations VII and III during summer 2006 and spring 2006. The bottom values ranged between 0.28 and $2.31 \mu \mathrm{mol} / \mathrm{l}$ (average $0.98 \mu$ $\mathrm{mol} / \mathrm{l}$ ) at stations VIII and III during summer and spring respectively. Generally, the DIP concentrations of the Bay water showed a decrease with depth. Based on annual averages, the surface water varied between average of 0.44 and $2.56 \mu$ $\mathrm{mol} / \mathrm{l}$ at stations VIII and III, respectively. The corresponding bottom averages scored 0.35 and $2.12 \mu \mathrm{mol} / \mathrm{l}$ at the same stations. Generally, the calculated ratios for $\mathrm{N}$ : $\mathrm{P}$ (Tables 4 and 5 ) were more than that of Redfield ratio $\mathrm{N}: \mathrm{P}=16: 1$ (Redfield et al.,1963). Thus, phosphorus was the limiting factor for phytoplankton growth in the study area.

Table (4). The seasonal range, mean and N:P ratio values of nutrient salts ( $\mu \mathrm{mol} / \mathrm{l})$ of surface water samples in the area of investigation during 2006-2007.

\begin{tabular}{|c|c|c|c|c|c|}
\hline Parameter & $\begin{array}{l}\text { Spring } \\
(2006)\end{array}$ & $\begin{array}{l}\text { Summer } \\
(2006)\end{array}$ & $\begin{array}{l}\text { Autumn } \\
\text { (2006) }\end{array}$ & $\begin{array}{l}\text { Winter } \\
(2007)\end{array}$ & $\begin{array}{c}\text { Annual } \\
\text { Mean }\end{array}$ \\
\hline Nitrite & $\begin{array}{c}1.80-4.95 \\
(2.73)\end{array}$ & $\begin{array}{c}0.70-3.06 \\
(1.73)\end{array}$ & $\begin{array}{c}1.64-3.24 \\
(2.22)\end{array}$ & $\begin{array}{c}1.72-4.12 \\
(2.51)\end{array}$ & $\begin{array}{c}0.70-4.95 \\
(2.30)\end{array}$ \\
\hline Nitrate & $\begin{array}{c}8.25-20.85 \\
(14.17)\end{array}$ & $\begin{array}{c}4.64-14.85 \\
(9.49)\end{array}$ & $\begin{array}{c}5.21-16.15 \\
(10.74)\end{array}$ & $\begin{array}{c}7.75-19.56 \\
(12.60)\end{array}$ & $\begin{array}{c}4.64-20.85 \\
(11.75)\end{array}$ \\
\hline Ammonia & $\begin{array}{c}4.10-16.70 \\
(8.23)\end{array}$ & $\begin{array}{c}3.12-9.20 \\
(5.92)\end{array}$ & $\begin{array}{c}3.25-10.95 \\
\quad(6.16)\end{array}$ & $\begin{array}{c}3.50-12.50 \\
(7.25)\end{array}$ & $\begin{array}{c}3.12-16.70 \\
(6.89)\end{array}$ \\
\hline $\begin{array}{l}\text { Dissolved inorganic } \\
\text { phosphorous }\end{array}$ & $\begin{array}{c}0.56-3.04 \\
(1.39)\end{array}$ & $\begin{array}{c}0.32-2.16 \\
(0.90)\end{array}$ & $\begin{array}{c}0.40-2.08 \\
(1.10)\end{array}$ & $\begin{array}{c}0.48-2.56 \\
(1.11)\end{array}$ & $\begin{array}{c}0.32-3.04 \\
(1.13)\end{array}$ \\
\hline $\mathrm{N}: \mathrm{P}$ ratio & 18.08 & 19.04 & 17.38 & 20.14 & 18.53 \\
\hline
\end{tabular}


Table (5). The seasonal range, mean and N:P ratio values of nutrient salts ( $\mu \mathrm{mol} / \mathrm{l})$ of the bottom water samples in the area of investigation during 2006-2007.

\begin{tabular}{|c|c|c|c|c|c|}
\hline Season & $\begin{array}{c}\text { Spring } \\
(2006)\end{array}$ & $\begin{array}{c}\text { Summer } \\
(2006)\end{array}$ & $\begin{array}{c}\text { Autumn } \\
(2006)\end{array}$ & $\begin{array}{c}\text { Winter } \\
(2007)\end{array}$ & $\begin{array}{c}\text { Annual } \\
\text { Mean }\end{array}$ \\
\hline Parameter & $1.74-3.82$ & $0.82-2.56$ & $1.64-2.98$ & $1.53-3.56$ & $1.43-3.59$ \\
$(2.36)$ & $(1.48)$ & $(2.09)$ & $(2.25)$ & $(2.05)$ \\
\hline Nitrite & $\begin{array}{c}(2.14-18.77 \\
(12.86)\end{array}$ & $\begin{array}{c}3.20-12.80 \\
(8.04)\end{array}$ & $\begin{array}{c}4.08-15.60 \\
(9.23)\end{array}$ & $\begin{array}{c}6.56-18.14 \\
(11.42)\end{array}$ & $\begin{array}{c}5.25-16.33 \\
(10.39)\end{array}$ \\
\hline Ammonia & $3.20-11.30$ & $2.35-7.65$ & $2.66-7.95$ & $2.95-9.75$ & $2.79-9.16$ \\
& $(6.76)$ & $(5.15)$ & $(5.10)$ & $(6.04)$ & $(5.76)$ \\
\hline Dissolved inorganic & $0.44-2.31$ & $0.28-1.88$ & $0.30-2.08$ & $0.36-2.22$ & $0.35-2.12$ \\
phosphorous & $(1.22)$ & $(0.78)$ & $(0.96)$ & $(0.96)$ & $(0.98)$ \\
\hline N:P ratio & 18.02 & 18.07 & 17.10 & 20.53 & 18.57 \\
\hline
\end{tabular}

Table (6). The mean values of hydro chemical and nutrients data in Suez Bay and other surrounding regions.

\begin{tabular}{|l|c|c|c|c|c|c|c|c|}
\hline $\begin{array}{c}\text { Parameter } \\
\text { Area }\end{array}$ & $\mathrm{pH}$ & $\begin{array}{c}\mathrm{DO} \\
\mathrm{mg} \mathrm{O}_{2} / \mathrm{l}\end{array}$ & $\begin{array}{c}\mathrm{S} \\
\% \mathrm{o}\end{array}$ & $\begin{array}{c}\mathrm{NH}_{3} \\
\mu \mathrm{M} / \mathrm{l}\end{array}$ & $\begin{array}{c}\mathrm{NO}_{2} \\
\mu \mathrm{M} / \mathrm{l}\end{array}$ & $\begin{array}{c}\mathrm{NO}_{3} \\
\mu \mathrm{M} / \mathrm{l}\end{array}$ & $\begin{array}{c}\mathrm{PO}_{4} \\
\mu \mathrm{M} / \mathrm{l}\end{array}$ & References \\
\hline Suez Bay & 8.17 & 9.38 & 41.50 & 6.89 & 2.30 & 11.75 & 1.13 & Present study \\
\hline Suez Bay & 8.23 & 4.76 & 41.99 & 3.25 & 0.49 & 1.48 & 0.85 & Hamed,1992 \\
\hline Suez Bay & 8.17 & 4.70 & 41.76 & 8.86 & 0.33 & 3.42 & 0.45 & Mohamed,1994 \\
\hline Gulf of Suez & 8.15 & 5.56 & 41.24 & 1.54 & 0.20 & 0.52 & 0.47 & Hamed.1996 \\
\hline Suez Canal & 8.10 & 5.34 & 42.63 & 2.44 & 0.59 & 2.03 & 0.81 & Hamed.1996 \\
\hline Al-Khor, Suez & 8.23 & 4.80 & 41.80 & 3.54 & 0.38 & 2.06 & 0.62 & Hamed.1998 \\
\hline Suez Bay & 8.32 & 4.90 & 41.36 & 5.85 & 0.77 & 3.11 & 0.94 & Soliman,1994-1995 \\
\hline Suez Bay & 8.24 & 4.91 & 41.60 & 6.33 & & & 0.36 & Soliman,1990-1991 \\
\hline Oligotrophic level & & & & 0.51 & & 0.51 & 0.05 & Strivanic,Strin, \\
1982
\end{tabular}

\section{REFERENCES}

Abdallah, A. M.; El-Samra, M. I. and Hamed, M. H. (1994). Journal of Environmental Science, Mansoura Univ., Faculty of Science. 7: 111.

Cole,G.E. (1979)."Text book of Limnology"2 ${ }^{\text {nd }}$ Eds. C. V. Mosby Company. 426pp.

Cooper,L.H.N. (1948). In: Introduction to marine chemistry,J.P.Riley and R.Chester (eds) 1971, Academic Press, London, New York.

Fahmy, M. A.; Sheriadah, M. A.; Aboul Soued, A.; Abdel Rahman, S. M. and Shindy, M. (2005). Hydrogen and chemical characteristics of the coastal water along the Gulf of Suez. Egyptian Journal of Aquatic Research, 31: 1-14.

Franco, P. (1983). Fattori influent sulla productivita primaria dell Adriatico Settentrionale. Proc. Int. Cont. Prpblems of the Adriatic Sea, Trieste pp.155-174. 
Grasshoff, K. (1983). Methods of seawater analysis. Second Extended Addition New York, verlaghe Chemie, 317 pp.

Hamed, M. A. (1996). Determination of some micro elements in aquatic ecosystem and their realtion to the efficiency of aquatic life, Ph.D. Thesis, Faculty of Science, Mansoura University, Egypt.

Hamed, M. A. (1998). Environmental studies on Al-Khor area, Suez, Egypt, J. of .Environmental Science, 15:181-201.

Hamed, M. A. (1992). Seawater quality at the northern part of the gulf of Suez and the nearby area of the Suez canal, M.Sc.Thesis,Faculty of Science, Mansoura University, Egypt.

Hutchinson, G.B. (1957). A Treutisc on Limnology. Vol. 1 Geography, Physics and Chem. New York, John Wily, 1015 pp.

Mohamed, A. A. (1994). Study of iodine cycle in Suez Bay, M. Sc. Thesis, Faculty of Science, Helwan, Egypt.

Meshal, A. M. (1970). Water pollution in the Suez Bay, Bull. Inst. Oceanogr. \& Fisheries, 9: 463-470.

Mohamed, A. A. (1994). Study of iodine cycle in Suez Bay, M. Sc. Thesis, Faculty of Science, Helwan, Egypt.

Morcos, S. A. (1960)."The tidal currents in the southern part of Suez canal". Gen. Ass. of Helsinki, 51:307-313.

Morcos, S. A. (1970). "Physical and chemical Oceanography of the Red Sea. Oceanogr. Mar. Biol. Annu. Rev., 8, (73):202.

Nassar, M. Z. and Hamed, M. A. (2003): Phytoplankton standing crop and species diversity in relation to some water characteristics of Suez Bay (Red Sea).

Redfield, A.C.; Katchum, B. H. and Richards, S.A. (1963).The influence of organisms on the composition of sea water, In: the sea, vol.2, M. N. Hill (Ed.) John Wily and Sons, New York, pp.26-77.

Riley, J. P. and Chester, R. (1971). Introduction to marine chemistry. Academic Press, 457pp. 
Severdrup, H. U. (1942). Johnson,M.W. and Fleming, R.H., Asia Pub.House.1087pp.

Sillen, (1961). C / F. Worner, R. A. (1972). Marine chemistry, Wiley Interscience, London, New York.

Skrivanic, V. and Strin, J. (1982). P: Basic physical.chemical and biological data reports R.V.”Mohorov ICIC Adriatic cruises 1974-76 Hydrographic Inst. of the Yugoslav Navy. Split 175pp.

Yosry, A. S. (1994). Physicochemical studies of some sulphur compounds and their effect as antifouling and anticorrosion" M. Sc. Zagazig University.

Yosry, A. S. (1999). Preparation of new marine paints containing carbonyl derivatives of some thiamine triazole compounds and their application in marine environment, Ph.D. Faculty of Science, Zagazig University,

Zentara, S. J. and Kamykowski, D. (1977). Latitudinal relationships among temperature and selected plant nutrients along along the west coast of north and south America. J. Mar. Res., 35(2):321-337. 